\title{
Evolución del monacato agustiniano
}

El año 1944 me reuní en Valladolid con el P. César Vaca para planear un proyecto de comentario a la Regla de S. Agustín y a su monacato. Ambos habíamos sido encargados de explicar a los jóvenes ese tema, y nos encontrábamos ante la misma dificultad: ausencia de explicaciones adecuadas a la situación de nuestros jóvenes candidatos. Teníamos algunos comentarios antiguos insuficientes, pero necesitábamos conocer, por un lado el auténtico pensamiento de S. Agustín, y por otro lado actualizarlo, ajustarlo a las circunstancias actuales. Después de algunas reflexiones, tomamos la determinación de preparar dos ensnyos: yo me encargaría de revisar las Obras de S. Agustín, de reunir los textos que pudieran explicar auténticamente su pensamiento. El P. César se encargaría de una actualización, esto es, de la traducción a un lenguaje moderno e interpretación moderna del pensamiento auténtico. Poco tiempo después fuimos cumpliendo nuestro propósito ', provocando el celo de otros autores, que vendrían a subsanar nuestras deficiencias. No podemos sentirnos defraudados ante el éxito de nuestra «provocación», ya que hoy tenemos una abundante literatura acerca de la Regla y del monacato de S. Agustín.

En tales materias nunca se llega al término. Por un lado, el pensamiento auténtico de S. Agustín necesita una continua revisión. Los especialistas se han ido inclinando hacia un Agustín hipotético, envuelto en una atmósfera de eternidad helénica, en un abstraccionismo clásico. De nada sirve advertir que el Santo se convirtió a los 32 años y que aún apenas tenía una formación cristiana, o que esa formación tardía fue lenta y progresiva. De nada sirve los descubrimientos actuales de los salmos e himnos maniqueos, de la religiosidad maniquea, o del «carácter» que imprime el Dualismo en sus adeptos: el Agustín auténtico queda siempre al margen, y en su lugar tenemos un Agustín clásico, un «agustinismo doctrinario», semejante al «agustinismo político» del siglo XIV. Nos encontramos con un neoplatónico incoloro e insípido, que amalgama doctrinas cristianas, tratando de insuflarles un espíritu helenista.

1. Cilleruelo, L., El monacato de S. Agustin y su Regla, Valladolid 1947; VaCA, C., La vida religiosa en S. Agustín, I-II, Ávila 1948 y III, Madrid 1955. 
En el aspecto monástico ese defecto se agrava por la simplificación que se realiza con la Regula Augustini. No se toman en serio las dificultades acerca de su autenticidad en sentido estricto, y se considera desmoralizador y derrotista a quien pretenda exponer tales dificultades. Considerando como un dogma la autenticidad, se pretende explicar el pensamiento agustiniano por la $R \boldsymbol{e}$ gula, y no viceversa la Regula por el pensamiento agustiniano. El amargo resultado de esa táctica me lo ha revelado la comunicación de un especialista, que me escribe: «He ahí el ideal agustiniano con que tanto soñé; pero que en la realidad práctica tanto me decepcionó, que no puede menos de perder la fe en él».

Por otro lado, la situación ha cambiado desde el año 1944. La crisis del monacato se ha radicalizado. Hoy nos preguntamos si la vida religiosa misma tiene sentido y cuál es ese sentido. Distinguimos diferentes tipos de monacato y confesamos que el «agustiniano» es típico, característico.

Dos hermosos libros, aparecidos últimamente, con los que se cierra, por decirlo así, un «ciclo doctrinal», van a darnos ocasión para volver de nuevo sobre el auténtico pensamiento de S. Agustín y sobre el sentido concreto de su monacato ${ }^{2}$. El problema es radicalmente histórico, y sólo con un método histórico se puede plantear y resolver. Utilizamos el término «evolución» en su sentido obvio, para dar a entender que hay diferentes etapas o fases, pero no desligadas o rotas, sino ligadas y animadas por un espíritu fundamental y unitario, o por decirlo así, por una ley interna, que S. Agustín llamaría «razón seminal». Hoy esta tarea parece necesaria, una vez que el Vaticano II nos ha marcado la primera norma de una renovación de la vida religiosa: «fidelidad al carisma del Fundador" ' ${ }^{3}$. Si suponemos la autenticidad de la Regula Augustini, deberemos suponer también que S. Agustín es un Fundador, y que los llamados «agustinos» se deberán inspirar de un modo especial en el pensamiento del Santo, y dar muestras de una fidelidad inalterable y devota al Fundador, recogiendo su «carisma», si realmente desean merecer el título de «agustinos».

Otro tanto deberíamos decir del segundo problema, el problema de la «actualización» del pensamiento agustiniano, pero eso me incumbe a mí. Es claro que el Vaticano II marcó también la segunda pauta de la renovación de la vida religiosa, que es la «actualización», traducción al lenguaje moderno, a la ideologia moderna, y una interpretación moderna ${ }^{4}$. En ese sentido debería reeditarse, «actualizado», el libro del P. César Vaca, ya que la situación ac-

2. Manrique, A. y Salas, A., Evangelio y Comunidad. Raices biblicas de la Consagración a Dios en S. Agustín, Madrid 1978. Verheijen, L., Nouvelle approche de la Règle de S. Augustin, Abbaye de Bellefontaine 1980.

3. Perfectae Caritatis, 2. Cfr. Tillard, J.M.R., «Le grandi legi del Rinnovamento della vita religiosa», en Il Rinnovamento della Vita Religiosa, Firenze 1968. Trad. del francés, 1967.

4. Ibid. 
tual reclama imperiosamente esa «actualización». Valdría la pena de ensayar esa «actualización», ya que la crisis nos va llevando poco a poco a una situación semejante a la que S. Agustín contempló a la hora de convertirse. A mi juicio, el pensamiento agustiniano volverá pronto a jugar un papel decisivo en la batalla que el monacato actual tendrá que librar, si quiere sobrevivir. El monacato agustiniano no es en realidad un problema «monástico», sino un problema «eclesiológico», un problema de la Iglesia. El Papa actual repetía el 8 de marzo de este año de 1980: «sin las órdenes religiosas, la Iglesia no sería Iglesia». Esa declaración da la respuesta a las discusiones provocadas por el Vaticano II, a la distinción entre Jerarquía y Espíritu, entre Institución y formas temporales y coyunturales de la misma ${ }^{5}$. Justamente, ese pensamiento profundo parece corresponder al pensamiento agustiniano: una Iglesia de Cristo sin órdenes religiosas parece una utopía poética y empresarial, que pronto quedaría sometida a las leyes de la sociedad de consumo. Carecería de un principio de renovación, al vivir satisfecha de sí misma, sin su característica aspiración a lo perfecto, a un más allá, a una ambición misionera, erística, polémica, maternal. El espíritu de Agustín, siempre vivo en la Iglesia, será siempre una fuente de renovación, de evolución, de insatisfacción constitutiva: es una ley de evolución y desarrollo ulterior, ya que mantiene viva la denuncia maniquea: $;$ «Cuidado con que la Iglesia se convierta en una organización de «semicristianos»!

\section{Primera etapa}

Las imposiciones de la sociología nos obligan hoy a considerar ante todo el contexto mediato e inmediato de cualquier fenómeno histórico, y por ende también del monacato. El contexto lejano está dado por el dualismo que reinaba en todo el mundo prácticamente por obra del helenismo y concretamente del gnosticismo filosófico y religioso. Muchos autores estiman que el monacato cristiano es un fenómeno específico independiente, nacido de la misma sustancia cristiana. Pero entonces no vemos por qué no surgió en los primeros tiempos del cristianismo, o por qué revistió determinadas características que eran conocidas en otras filosofías o misterios. Limitándonos al Occidente y en concreto al ambiente en que S. Agustín pudo pensar en un monacato, deberemos proceder analizando los hechos, antes que los argumentos.

5. «La vida religiosa no pertenece a la esencia de la Iglesia, si se considera a ésta en su estructura, en cuanto sociedad ordenada y jerárquica, instituida como tal por el Señor; pero pertenece inalienablemente a la Iglesia, cuando ésta es contemplada en el acto de responder a la llamada de su Señor, cuando realiza su misión, su bien común, o su finalidad de santidad; en breve, cuando vive eso que está llamada a ser". (Congar, Y., Il Rinnovamento..., Prefazione, p. 14). 
En la época en que Agustín se convirtió había ya ideado un plan de vida común, que nos conviene examinar, porque todavía no tenía ninguna influencia cristiana: se trataba de un ensayo sociológico, que sólo podía fundarse en una gnosis filosófica, que podremos identificar con el «Neopitagorismo y Maniqueísmo». El mismo Santo nos ha dejado una descripción del proyecto ${ }^{6}$.

Comienza Agustín su descripción, anunciando la motivación del proyecto. La turbulencia de la vida social resulta molesta y el grupo de amigos la detesta. Piensan en ella y discuten sobre ella, dando vueltas a un proyecto que ya tienen casi aprobado: separarse de la sociedad mundana, y vivir el ocio filosófico. Ese modo de hablar refleja la gnosis filosófica, animada desde antiguo por un platonismo fundamental, un dualismo antropológico de cuerpo y alma. Platón recoge la herencia órfica y pitagórica, y coloca el telos del hombre en la theoría, en la contemplación (otium). Los estoicos reorganizaron el platonismo dentro de su sistema inmanente, pero continuaron repitiendo los mismos términos, manteniendo su religión inmanente. Cicerón identifica la vita beata con la similitudo Dei, y realiza por sí mismo en este mundo el telos, el ideal del sabio ${ }^{7}$. Esa misma es la insistente postura de Séneca ${ }^{8}$. De ese modo, querían realizar los estoicos la apoteosis del mundo y del hombre. La admiración y la contemplación, como finalidad del hombre, no son sólo fenómenos psicológicos, sino el camino de la salvación ${ }^{9}$.

También la Academia, que Agustín, conoció, mantenía las tendencias edificantes de la tradición antropológica de Platón. Parece que el Luculo, de Cicerón, impresionó extraordinariamente a Agustín ${ }^{10}$. La contemplación es la terapéutica del alma; la Academia, al predicar el escepticismo, cultiva la ironía y en el fondo mantiene el ideal platónico ${ }^{11}$. Sin embargo, la "autarquía» estoica cobró entre los latinos un pesimismo indudable ${ }^{12}$. La idea de la muerte toma un papel decisivo, en cuanto reintegración a la naturaleza misteriosa ${ }^{13}$.

6. Et multi amici agitaveramus animo, et colloquentes ac detestantes turbulentas humanae vitae molestias, pene iam firmaveramus, remoti a turbis otiose vivere; id otium sic moliti, ut... (Confess. VI, 14,24 PL 32,731).

7. CICERÓN, De natura deorum, II, 78,154.

8. SÉNECA, $E p .31,5 ; 9,3 ; 75,18 ; 53,11$, etc.

9. CICERON, De finibus, 2,$40 ; 5,11$, etc.

10. Cicerón, Lucullus, 2,$6 ; 4,12 ; 5,15$ etc.

11. S. Agustin, Ep. 1,1,3.

12. Nos multa alligant, multa debilitant, diu in istis vitiis iacuimus, elui difficile est; non enim inquinati sumus sed infecti; ne ab alia imagine ad aliam transeamus, hoc quaeram, quod saepe mecum despicio, quid ita nos stultitia tam pertinaciter teneat? (SENECA, Ep. 59,9;65,10).

13. WlosoK, A., Laktanz und die philosophische Gnosis, Heidelberg 1960, p. 44s. Wlosok recuerda que si Platón tomó de los Misterios su Filosofía, ese procedimiento era reversible. Fácilmente los Misterios podían utilizar a su vez la Filosofía de Platón para fines religiosos. Ibid, p. 14 y 15. Tal podía ser el caso del maniqueo Agustín, al utilizar los elementos platónicos del estoicismo. 
Tras esta ligera reflexión, podríamos concluir que Agustín y sus amigos constituían un cenáculo filosófico. Pero eso contradice al modo de ser del mismo Agustín y a la evolución de su existencia. Aunque el «proyecto de vida común» parezca una realización de las perspectivas del Hortensio, que invitó a Agustín a buscar "a Dios y la vida bienaventurada» ${ }^{14}$, desde el momento en que Agustín se hizo maniqueo, subordinó la filosofía a la religión ${ }^{15}$. Con todo derecho podemos calificar su postura de "gnosis filosófica». Rechaza la autarquía y la inmanencia de los estoicos, y acepta en absoluto la trascendencia religiosa y concretamente la trascendencia de la verdad, o la solución religiosa del problema gnoseológico. De ahí su inclinación al neopitagorismo, como veremos a continuación.

En efecto, Agustín apunta las bases en que había de asentar su fórmula de vida común: 1) comunidad de bienes; 2 ) cultivo de la amistad; 3 ) encomienda de la administración a dos magistrados ${ }^{16}$.

Verheijen se ha detenido a verificar la relación entre Agustín y Pitágoras en su último libro ${ }^{17}$. En un apartado que intitula «hacia la belleza espiritual», deja al margen los salmos e himnos maniqueos, que hablan continuamente de la belleza espiritual, y se fija en la relación que halla entre la doctrina de Pitágoras y los Diálogos de Casiciaco, especialmente en el sistema catártico y pedagógico de los pitagóricos ${ }^{18}$. Tras un cotejo muy erudito y excesivamente generoso, V:rheijen concluye que el plan didáctico de Agustín procede de Pitágoras. Ninguna dificultad hay para negarlo, ya que consta explicitamente ${ }^{19}$; el interés está en la coincidencia de los tres elementos, que Agustín presenta, como bases de su «vida común», con las bases pitagóricas.

Verheijen se apoya en un artículo del P. Courcelle. Éste, muy cautamente, advierte: «esa fundación, tal como la enfocan nuestros amigos de origen maniqueo, ha podido ser influenciada por sus lecturas filosóficas: evoca sobre

14. Liber exhortationem continet ad philosophiam, et... mutavit affectum meum, et ad Teipsum, Domine, mutavit praeces meas... Hoc solum me in tanta fragrantia refrangebat, quod nomen Christi non erat ibi. (Confess. III, 4,7s PL 32,685s).

15. Seducebamur et seducebamus... palam per doctrinas quas liberales vocant, occulte autem falso nomine religionis! (Confess. IV, 1,1 PL 32,693). Sería ingenuo pensar que Agustín es un filossofo, a la manera de los griegos o de Cicerón y Séneca. Su filosofía es siempre «religiosa».

16. Ut si quid habere possemus, conferremus in medium... Ut per amicitiae sinceritatem non esset aliud huius et aliud illius... esse posse decem ferme homines in eadem societate... Ut bini annui tanquam magistratus omnia necessaria curarent, caeteris quietis. (Confess. VI, 14,24 PL 32,731).

17. Verheijen, L., Nouvelle Approche... p. 201. Parece infantil dividir la Regula en dos partes: una, formada por tres palabras (spiritalis pulchritudinis amatores y otra por todo el resto. Parece asimismo sospechoso omitir la influencia neoplatónica en el carácter de la belleza, en los diálogos de Casiciaco. Pero está bien todo, para hacernos notar el carácter pitagórico, o la fuente pitagórica, en que Agustín se inspira, seguramente según las exposiciones de Varrón.

18. De Ordine, II, 20,53 PL 32,1020. Cfr. Retract. I, 3,3 PL 32,589.

19. Ibid. II, 20,54 PL 32,1020. 
todo, a mi parecer, la vida pitagórica: evolucionaban hacia un neoplatonismo profundamente impregnado de pitagorismo") ${ }^{20}$. Por su parte, Verheijen se lamenta de la falta de estudios sobre la relación entre maniqueísmo y patagorismo. Cita a Svoboda, el cual se remite a los Acta Archelai, 51 y 55 (PG. 10,1517 s y 1523 s, y se contenta con relacionar la Regula con el De Ordine, lo que parece excesivamente modesto ${ }^{21}$. Pero hace constar una interesante conclusión: «Esta lenta evolución ha tenido como consecuencia el traspaso de lo mejor de la ética clásica a la concepción monástica de S. Agustín» ${ }^{22}$. Pero quizá el problema es profundo.

Mientras Agustín y sus amigos planeaban una «vida común» en Milán, otro amigo de Agustín, Constancio, que había hospedado al africano en Roma, hizo un ensayo semejante con los «perfectos» maniqueos ${ }^{23}$. Constancio se comprometía a reunir en su casa y mantener a sus expensas a todos los perfectos que estuviesen dispuestos a vivir secundum illa praecepta. Los obispos, que deberían estimular el cumplimiento de tales preceptos, hicieron una oposición y obstrucción inesperadas. Sólo uno de ellos, rudo y áspero, pareció aceptar el rigorismo que convenía a su carácter. Constancio lo buscó y al fin logró comprometerlo. El obispo dio el ejemplo, y los maniqueos perfectos se sintieron obligados a vivir en común. Se redactó una Regla, según la Epístola de Mani ${ }^{24}$, en la que se contenían los preceptos taxativos de gobierno, de manera que el quebrantarlos significaba obrar «fuera de la ley» ${ }^{25}$. Todo esto lle-

20. Courcelle, P., Les Confessions de S. Augustin dans la tradition litteraire, Paris 1963. Courcelle toma la precaución de mencionar el maniqueísmo; esa cautela parece lo más importante, para explicar por qué precisamente a este punto de amigos se les ocurrió un pitagorismo anacrónico. ¿Querían resucitar el pitagorismo, o querían otra cosa, buscando un interés religioso? Ese es el problema principal.

21. Verheijen, $l$. $c .$, p. 238. Sin incurrir en los excesos de Beausobre, el cual identifica al pitagorismo con el maniqueísmo, afirmando que Pitágoras era maniqueo, no debemos olvidar la relación del platonismo con el pitagorismo, y los avatares de esa relación, sobre todo en Alejandría. Si a eso añadimos el carácter dualista y "gnóstico» del maniqueísmo, adivinaremos la complejidad de las fuentes de Agustín, y al mismo tiempo el esfuerzo de síntesis que trataba de realizar a su llegada a Milán. Los Acta Archelai serían un simple ejemplo de una síntesis.

22. L.c., p. 240. Por lo demás, la relación de la Regula con Pitágoras y con la ética clásica no pasa de ser una mera posibilidad, ya que son tantas las doctrinas que hablan de hermosura espiritual, de la preferencia del amor al temor, y del bien común al particular.

23. De mor. Eccl. II, 20,74, PL 32,1376. Constancio era maniqueo y oyente, como Agustín. También dudaba de la moralidad de los «perfectos». Agustín constribuyó a desenganarle de las doctrinas dudosas. Cuando Agustín volvió a pasar por Roma, al año siguiente, Constancio le narró todo lo ocurrido. Pero ya estaba Agustín enterado del caso en Milán: Eo enim res erupit, ut occulta esse non posset absentibus; et ego quidam postea Romae cum essem, omnia vera me audisse firmavi. Ibid., ¿Puede ser casual la coincidencia en el planteamiento, aunque Agustín en Milán se hubiese distanciado ya mucho del maniqueísmo?

24. Proposita est vivendi regula de Manichaei Epistola. Ibid.

25. Praeter regulam. Ibid. Agustín lo aplica principalmente a la vida común. El obispo obra praeter regulam, porque no se contenta con la mesa común y tiene comida particular, y dinero particular. 
gó a oídos de Agustín y de sus amigos en Milán; y puesto que más tarde Agustín fue comprobando los hechos, no podemos pensar que se tratara de coincidencias casuales. Hay sin duda una dialógica y una suerte de causalidad en estos ensayos; esa dialógica corresponde al proceso que en esos momentos está padeciendo el mismo Agustín, como lo testifican las Confesiones en su modo de ir narrando los acontecimentos. Por eso dice muy bien Courcelle que se trata de una evolución, aunque no hacia el Neoplatonismo, sino hacia el Cristianismo ${ }^{26}$.

En suma, se trata de un «proceso de conversión», provocado por una dialógica espiritual, por la discordancia entre el ideal y la realidad. El contexto de las Confesiones no puede ser más claro. Todo el libro VI de las Confesiones está dedicado a ese tema. Agustín recuerda que ya no era ni maniqueo ni católico: acude a escuchar los sermones de S. Ambrosio, va aceptando la autoridad de la Biblia, considera su vida como una miseria, según se ve en el ejemplo del mendigo borracho, en el colorido religioso que da a sus lecturas de Cicerón, en las discusiones con sus amigos acerca del «género de vida» que debía emprender, en sus opiniones acerca del matrimonio, y del telos de la existencia humana ${ }^{27}$. Cabalmente el sentimiento religioso contribuye a dramatizar la situación de angustia. Esa es la diferencia entre estos hombres sinceros y los farsantes que utilizan la religión para hacer filosofías baratas ${ }^{28}$.

26. «Nuestros amigos ex-maniqueos están en trance de evolucionar hacia un neoplatonismo, impregnado de pitagorismo». Courcelle, l.c.

27. Veneram in profundum maris. Confess. VI, 1,1; Dubitabam de illis omnibus et inveniri posse viam vitae minime putabam, Id. 2; ad quaerendum intentus, è ad disserendum inquietus erat animus meus, Id. 3; acrior cura rodebat intima mea... confundebar et convertebar, Id.4; Id credebam aliquando robustius, aliquando exilius, Id. 5; Inhiabam honoribus, lucris, conjugio; et Tu irridebas. Patiebar in eis cupiditatibus amarissimas difficultates... Quam misera erat anima mea! Id. 6. Cuenta luego la vida de Alipio, y continúa la descripción de su estado de ánimo: et ego maxime mirabar, satagens et recolens, quam longum tempus esset ab undevigesimo anno aetatis meae, quo fervere coeperam studio sapientiae... relinquere omnes vanarum cupiditatum spes inanes et insanias mendaces; et ecce jam tricenariam aetatem gerebam, in eodem luto haesitans aviditate fruendi praesentibus, fugientibus et dissipantibus me, dum dico: cras inveniam... Pereant omnia, et dimitamus haec vana et inania; conferamus nos ad solam inquisitionem veritatis. Vita haec misera est, mors incerta... Si subito obrepat, quomodo hinc exibimus?... Alternabant hi venti et impellebant huc atque illuc cor meum, Id. 11; Prohibebat me sane Alypius a uxore ducenda, Id. 12. Así continúa con la escena de la vida común: «muchos amigos planeábamos...»Id. 14. Y al terminar la descripción, sigue: Interea peccata mea multiplicabantur. Id. 15. Concluye el Capítulo: O tortuosas vias! Vae animae audaci quae speravit, si a te recessisset, se aliquid melius habituram! Versa et reversa in tergum, et in latera, et in ventrem, et dura sunt omnia; et Tu solus requies! Id, 16. Al redactar sus Confess., Agustín acentúa el colorido cristiano de sus recuerdos, pero refleja sin duda un estado de ánimo lleno de cansancio, fatiga, angustia, como preámbulos de una conversión que se ve venir. Y eso es suficiente, para comprender que el plan de vida común aprovechaba materiales filosóficos, pero para dedicarlos a un propósito religioso existencial. $\mathrm{Pa}$ ra el contexto del «plan», cfr. Confess. VI, cap. 11 y 12, PL 32, 728-730. El suceso tuvo lugar inmediatamente antes de la lectura de los platónicos. C. Acad. II, 2,5. 
Por lo mismo, hablamos de una primera etapa del monacato, ya que el sentido y valor de ese planteamiento viene dado por el contexto, por la dialógica interna, por la ley unitaria que se irá manifestando y desarrollando, aunque libremente, bajo el apremiante influjo de las circunstancias. Aceptamos plenamente la presentación filosófica, concretamente pitagórica, del «plan». Pero nos preguntamos si se trata de un «plan filosófico», y a eso respondemos que no: el aspecto filosófico es sólo el modo de plantear un problema religioso, de acuerdo con la tesis agustiniana de «hablar de artes liberales para introducir religión». Este planteamiento y solución es más claro en la relación de los preceptos con la hermosura espiritual, de la que tanto nos hablan los himnos y salmos maniqueos. Diremos pues que Constancio considera la «vida común» como un «orden» o Regula, en que se revela el valor filosófico de la moralidad o religiosidad maniquea. Agustín, a su vez, cansado de repetir durante once años cras, cras y quandiu haec, considera la «vida común» como un «orden» o Regula, en la que finalmente podrá realizar su consagración a la Sabiduría. Pero su sabiduría es religiosa. El pitagorismo se prestaba a esa interpretación. "Alipio me prohibía casarme, alegando que no podríamos vivir juntos, en un ocio seguro, en el amor de la sabiduría, como lo veníamos ansiando tanto tiempo hacía, si yo me casaba».

\section{Segunda etapa}

La escena del «plan de vida común» tuvo lugar inmediatamente antes de la lectura de los platónicos ${ }^{29}$. Esta lectura le abrió nuevos horizontes. Le liberó del materialismo maniqueo, y le proporcionó una nueva visión del Universo, mediante un error: este consistía en creer que, según los platónicos, Dios, el Dios verdadero de los cristianos, es el principio del ser, del conocer y del gozar. Ese error era muy fácil, ya que leyó a los platónicos con ojos cristianos. Pero en definitiva, 1) la lectura no le convirtió en otro hombre; 2) tampoco le

yo gozaba de Dios, ni traía contento en el mundo». Sta. Teresa de Jesús, Vida, 8,1. William James, en su libro The varieties of religious experience, dedica hermosos capítulos a describir estos dolores del alma que cuadran muy bien a Agustín; concretamente, al tratar de enfocar el problema de la conversión, dice: «el caso de S. Agustín es clásico». Pero no se trata sólo del fenómeno aislado de la «conversión» sino de su preparación, de su dialógica, y de lo que el mismo William James llama "voluntad dividida", que es el punto aquí tratado. Nos recuerda que Agustín desde joven pedía a Dios una castidad que estaba rehusando, mostrando así su división interna. $Y$ tanto James como Starbuck, al que él se remite, acentúan los preámbulos de la conversión como «convicción del pecado». También se remite James a Leuba, con la misma constatación: frente a los negociantes de la religión, que utilizan el templo para sus mercaderias, las almas «adoloridas» sienten la responsabilidad del «nobleza obliga» y cargan con ella. Como hay tantos que se llaman religiosos, y son tenderos de lucro y de palabras, Agustín se llamaba a sí mismo tendero de palabras y era profundamente religioso, místico.

29. C. Acad. II, 2,4 y 5 PL 32,921 . 
hizo un platónico auténtico, sino un manipulador del platonismo. Esas dos afirmaciones deberemos meditarlas para no incurrir en dos errores muy frecuentes entre nosotros. Después de la lectura de los platónicos, Agustín se sintió mejorado, engreído, pero no aliviado ni liberado ${ }^{30}$.

Como la situación angustiosa persistía, fue a consultar a Simpliciano sobre el género de vida que debía adoptar: en sus discusiones con los amigos se llegaba siempre a la conclusión de que «el género de vida» era imprescindible, si los proyectos sapienciales eran sinceros y no «veleidades platónicas». Agustín presenta a Simpliciano una alternativa entre una «vida secular» y una «vida sapiencial», que no se limita a la «vida filosófica», sino que implica un ascetismo comunitario: «Ya había oído yo de boca de la Verdad, que había eunucos que se habían mutilado por el Reino de los Cielos; pero la Verdad añadía: el que pueda comprender, comprenda (Mt 19,22). Ya había encontrado yo la perla preciosa, y tenía que venderlo todo para comprarla (Mt 13,46), pero ¡cavilaba!»" ${ }^{31}$.

¿Qué solución ofreció Simpliciano? Al mencionar Agustín su lectura de los platónicos, Simpliciano desvió el diálogo hacia la conversión de Victorino, estimando sin duda que era el mejor modo de contestar a la demanda de Agustín. Podemos colegir que le consideró como otro Victorino, como un filósofo idealista, que cree que la religión es tan sólo un asunto de interioridad. Era pues preciso empujarle, como a Victorino, hacia la constatación de que son las «posturas externas» las que revelan realmente una postura «interna», que por sí misma puede ser una mera veleidad, o un método de engañarse a sí mismo ${ }^{32}$. Simpliciano logró su objetivo: la narración de Agustín refleja perfectamente la dialógica de la conversión de Victorino y de la habilidad de Simpliciano.

Agustín quedó, pues, convencido, dispuesto a imitar a Victorino, no sólo en los propósitos de renuncia que venía cultivando desde la lectura del Hortensio, sino también en la misma renuncia a la cátedra, que era su profesión, y le dejaba inerme frente a las contingencias futuras. Agustín refleja su intole-

30. Garriebam quasi peritus... Non peritus sed periturus. Jam enim caeperam velle videri sapiens, plenus poena mea; et non flebam, insuper inflabar scientia. Confess. VII, 20,26 PL 32,747 .

31. Confess. VัIII, 1,1s. y 2,3s. PL 32,749s. Agustín presenta su problema como «camino» o como «modo» de andar «en el camino del Seffor». Pero más concretamente se refiere al matrimonio, sobre el que venía discutiendo con Alipio: ¿ Matrimonio o celibato? Ese era el problema radical de la «conversión».

32. Id. VIII, 2,3 PL 32,750. «No creeré en tu cristianismo, mientras no te vea en la iglesia de Cristo». Cuando Ponticiano viene y le habla de los monjes, Agustín resume su situación: «Mi vida era normal, pero crecía la angustia y cada día suspiraba ante Ti; frecuentaba la iglesia cuanto me lo permitía el trabajo, cuya pesadumbre me abrumaba» (Id. VIII, 6,13 PL 32,754. Deseaba imitar a Victorino: exarsi ad imitandum, Id. VIII, 5,10 PL 32,753. Pero del dicho al hecho hay gran trecho. 
rable situación consiguiente por medio del conflicto de las «dos voluntades» que le destrozan el alma, y que él identifica con la fórmula paulina de la lucha entre la carne y el espíritu $(\mathrm{Gal} 5 ; 17)$, que tanto aireaban los maniqueos, y que él había utilizado sin duda tantas veces ${ }^{33}$.

La situación es todavía más angustiosa. Al quedar eliminada la confusión, al desaparecer la máscara: «Se había desvanecido la excusa, que yo solía aducir, a saber: que no renunciaba al siglo y me ponía a servir a Dios porque la percepción de la verdad era incierta. Ahí tenía ya la verdad, cierta, pero rehusaba tu milicia» ${ }^{34}$.

Después de la consulta con Simpliciano, y ante el ejemplo de Victorino que él desea seguir, Agustín se encuentra en una situación sumamente compleja. Opta por el celibato, por la renuncia al matrimonio, y también por la renuncia a la cátedra, lo cual significa una suerte de voto de pobreza. Él mismo nos dice que el dinero y los honores (esperaba ser nombrado Gobernador de una Provincia) ya no le interesaban. Sin embargo del dicho al hecho hay largo trecho, como lo demostraba su propia experiencia del cras, cras, y del quamdiu haec? Por otro lado, su situación intelectual era embarazosa. Se iba inclinando hacia el Cristianismo, pero se mantenía aún en sus raíces maniqueas. No podían satisfacerle las informaciones filosóficas latinas sobre el academicismo, epicureísmo y estoicismo, que en realidad eran evasiones consolatorias y edificantes, pero no garantizaban seguridad alguna. El platonismo le había entusiasmado, y le ofrecía inapreciables ventajas, pero corría el riesgo de apoyarse en una falsa confianza.

A pesar de todo eso, Agustín se convirtió. La información que le ofreciera Ponticiano acerca del monacato católico, fue un golpe decisivo. Pero debemos examinar el suceso con calma. Porque Agustín no se adscribió a ese tipo de monacato de los «indoctos que arrebatan el cielo» ${ }^{35}$ sino que persiste en su «búsqueda de la sabiduría» en compañía de sus amigos ${ }^{36}$. En adelante se

33. Confess. VIII, 5,11 PL 32,753s. Es clara la presión de la herencia maniquea, ante la cual el platonismo es ineficaz.

34. La fórmula militare tibi recusabam (Confess. VIII, 5,11 PL 32,754) es un eco de la militia caelestis de las religiones mistéricas, y de todos los dualismos de influencia persa o irania; pero se relaciona concretamente con las fórmulas utilizadas por Apuleyo, con el cual se mantiene un cierto paralelismo: Sedulis obsequiis, et religiosis ministeriis, et tenacibus castimoniis, Apuleyo, Metamorf. XI, 6,767; in eos quorum sibi vitas in servitium deae nostrae maiestas vindicavit. Id. 15,783; da nomen sanctae huic militiae, cuius non olim sacramento etiam rogabaris, teque iam nunc obsequio religionis nostrae dedica et ministerii iugum subi voluntarium. Id. 15,784; tamen religiosa formidine retardabar, quod enim sedulo percontaveram difficile religionis obsequium et castimoniorum abstinentiam satis arduam cautoque circunspentam vitam, quae multis casibus subiacet, esse muniendam. Id. 19,794. Agustín, que había dialogado con Fausto de Milevi, conocía sin duda la distinción entre «cristianos» y «semicristianos»: pensaba que de ser cristiano, tendría que serlo del todo. Mientras no lo fuera de verdad, se consideraría siempre como un «tendero de palabras» y mercader que utiliza el templo para negociar con mayor éxito.

35. Confess. VIII, 8,19 PL 32,757.

36. Es su norma: concordar la fe con la razón. Confess. VI, 10 y 11 PL 32,728s. 
llama «siervo de Dios»; pero da ese mismo título a Simpliciano, sin ser monje ${ }^{37}$. Conoció y visitó los monasterios de Milán, pero él buscaba otra cosa diferente.

Reúne a sus amigos para deliberar, y en adelante utiliza el plural, no como plural de autor, sino como plural social, indicando un consenso colegiado para realizar un votum et propositum nostrum ${ }^{38}$. Los amigos estiman que el curso debe terminarse con regularidad, sin dar campanadas innecesarias; se aprovechan las vacaciones de las vendimias; se acepta el retiro de Casiciaco, como lugar de descanso provisional, y de preparación para el bautismo, pero el consejo lleva ya una orientación característica. Por un lado, lo que se busca es «la utilidad de la Iglesia» ${ }^{39}$. Por otro lado, queda consagrado el concepto de milicia: lo que esos amigos fundan es una milicia cristiana ${ }^{40}$.

La «búsqueda de la sabiduría» ya no tiene nada que ver con el Hortensio, sino que a lo sumo, se identifica con una eudaimonía, una búsqueda de la vida bienaventurada. Pero esta a su vez se identifica con una «semejanza de Dios», esto es, con una pietas, tal como la realizaban las religiones de misterios. Agustín continúa, pues, su tradición maniquea, pero en su nuevo ambiente cristiano. La gnosis, como revelación, prevalece; de hecho, Agustín habla del cristianismo en Casiciaco, como si se tratase de una religión de misterios ${ }^{41}$.

No insistiremos en el paralelismo entre Agustín y el Lucio del Asno de Oro, de Apuleyo ${ }^{42}$. Tampoco insistiremos en el carácter especial de la mística

37. Id. VIII, 1,1 PL 32,749.

38. Id. IX, 2,2 y 3 PL 32,764.

39. Simul eramus, simul habitaturi placito sancto. Quaerebamus quisnam locus nos utilius haberet servientes Tibi: pariter remeabamus in Africam. Id. IX, 8,17 PL 32,771.

40. Id. IX, 2,4 col. 765 y IX, 8,17 col. 771 . Sólo quedan cuatro. Al hacer el proyecto de vida común, calculaba que podrían reunirse como unos diez amigos (Confess. VI, 14,24 col. 731) y ahora veía que en realidad sólo contaba con Alipio y Evodio.

41. Doctrinarum oraculis editam. C. Acad. I, 1,1 PL 32,905; quem mysteria nobis tradunt Dei Filum. id. II, 1,1 col. 919; Numen aisti solum posse ostendere quid sit verum. Id. III, 5,11 y 6,13 col. 940; Qui divina mysteria tradiderunt. De Beata Vita, I, 4 PL 32,961; quam (philosophiam) sacra nostra meritissime detestantur. C. Acad. III, 19,42 PL 32,956; Patrem, Filium et Spiritum Sanctum docent veneranda mysteria, De Ordine, II, 5,16 PL 32, 1002.

42. Isis es la Sabiduría, que ofrece la revelación y la providencia: providentia mea inlucescit dies salutaris (Metamorph. XI, 5,5; la «conversión» del asno en hombre implica un servicio religioso y militar: (Id. 6,25); quo tutior sis atque munitior, da nomen sanctae huic militiae (Id, 15); el servicio comprende tres partes: 1) sedulis obsequiis; 2) religiosis ministeriis; 3) tenacibus castimoniis; se trata pues de culto, ética y castidad perfecta; al ordo monitionis (XI, 6 y 7) sigue el ordo reformationis (id. XI,13). La «curiosidad» fue el principio de la ruina y la iluminación es el principio de la paz y el ara de la misericordia $(I d$. XI, 15). La fortuna secunda ocupa la plaza de la fortuna infesta, caeca, nefaria; se trata de un nuevo nacimiento (XI, 16). Es una pena que Agustín no nos haya detallado su experiencia de la catequesis cristiana en el aspecto cúltico. También Lucio sudaba antes de consagrarse definitivamente (XI, 19) y llega a establecer una norma que Agustín aceptará y comprenderá más tarde: neque vocatus morari, nec non iussus festinare (XI, 21). El día de la consagración se denomina votum y el sacrificio es llamado obsequium; el acto de la iniciación, con el baño, recuerda las ceremonias del bautismo; se le retiran los vestidos «profa- 
racionalista, que Agustín parece adoptar; generalmente la llamamos «platónica», aunque no está de acuerdo ni con Platón ni con Plotino; parece una postura académica, en el sentido que Agustín toma del Lucullus de Cicerón: la duda metódica para combatir a los epicúreos y estoicos, y el saber esotérico, radicado en el platonismo, y centrado en los problemas de «Dios y del alma», como temática del platonismo del Imperio Romano ${ }^{43}$.

$\mathrm{Al}$ acabar las vacaciones de las vendimias, Agustín anuncia en Milán su retirada de la cátedra, alegando dos razones: que su salud precaria no le permitía continuar, y que se había determinado a servir a Dios ${ }^{44}$. Llegado el tiempo de bautizarse, volvió a Milán. Después de detallar tanto su conversión, nada nos dice de su bautismo ni de la guerra desencadenada por el tirano Máximo. Todo lo reduce a una frase: «juntos regresábamos al África. Y mientras estabamos en Ostia Tiberina, la madre murió» ${ }^{45}$. Se contenta con añadir: multa praetereo, quia multum festino. Eso es lo que nos sorprende, que tenga tanta prisa en una materia tan interesante, mientras se dedica a contarnos toda la vida de su santa madre. De sus recuerdos, al volver al África, no nos dice ni una palabra.

Sin embargo, no estamos mal informados. Sabemos, por ejemplo, lo que ocurrió cuando Agustín llegó al África. Pero antes de entrar en este terreno, necesitamos reflexionar sobre la idea de Agustín al proyectar su «monacato». Un «anacronismo» increíble se comete, al atribuir a Agustín ciertas teologías católicas, que él ignoraba en absoluto, cuando proyectó su nuevo género de vida, y que sólo mucho más tarde vinieron a florecer como revelaciones del monacato, y no como causas del mismo. Protestamos también contra el desatino que supone creer que Agustín es un hombre que nació en Milán o en Casiciaco, alegando que la lectura de los platónicos y la conversión al cristianismo, hicieron de él un «hombre nuevo». Al reflexionar sobre esto el biógrafo de san Agustín, Peter Brown, cita la fórmula francesa: Plus ça change, plus c'est la même chose ${ }^{46}$.

En efecto, la evolución de Agustín en profundidad es unitaria, y vale tanto para determinados momentos del pasado como del futuro de su existencia:

nos» y se le viste con un lienzo vulgar (rudi linteo). No podemos dudar de que Agustín conocía todo eso desde los bancos de la escuela, ya que Apuleyo era «un africano familiar a los africanos»; por otra parte, las Confesiones guardan un cierto paralelismo con las metamorfosis, servatis servandis. ¿Por qué Agustín no hace alusión a Apuleyo? Deducir de su silencio una ignorancia sería como creer que ignoraba el nombre de su concubina. En Agustín abundan esos silencios intencionados por razones religiosas, prudentes o personales. Pero hablar de «teología» cristiana sería un anacronismo, aunque por desgracia, se comete con excesiva frecuencia.

43. TheIler, W., Gott und Seele im kaiserlichen Denken: Fondation Hardt, Entretiens, III 1955, 65-91; Festugière, A.J., La revelation d'Hermes Trimégiste, II, Paris 1949, p. 341 ss.

44. Confess. IX, 5,13 PL 32,769.

45. Id. IX, 8,17 col. 771 .

46. Brown, P., Augustine of Hippo, London 1967, p. 111. 
el punto más importante de esa existencia es el maniqueísmo, que ocupó la parte más sólida de su vida, desde los diecinueve años hasta los treinta y dos. Si eso no tiene importancia ¿qué puede tener importancia en la vida de un hombre? Por consiguiente, tenemos que considerar los escritos de Casiciaco como muestras de un método ya consustancial con Agustín: hablar de artes liberales para introducir problemas religiosos. El platonismo juega el mismo papel que había jugado el estoicismo ciceroniano, como almacén de materiales «útiles», para sus construcciones religiosas. Pero el desafío que planteó a su madre, al hacerse maniqueo continúa ahora floreciente: en el libro De Ordinis, expone doctrinas pitagóricas, como suele decirse; pero al final advierte que las buenas costumbres tienen un objetivo: hacerse escuchar por Dios. Y añade: «para que se cumplan nuestros deseos devotamente, te adjudicamos a ti, madre, principalmente este negocio; creo sin dudarlo que por tus oraciones Dios me ha infundido esta determinación de no anteponer, ni querer, ni pensar, ni amar cosa alguna sobre la búsqueda de la verdad; no dejo de creer que así como por tus méritos hemos deseado ese bien tan alto, por tus oraciones lo alcanzaremos» ${ }^{47}$. Esto significa que Agustín, aunque hable de «artes liberales» o de «filosofías», en el fondo hace teología, como M. Jourdain hablaba en prosa sin saberlo, según dice humorísticamente Peter Brown ${ }^{48}$. Pero se trata de «teología agustiniana» no de teologías cristianas concretas. El mismo Brown, en esa página, nos recuerda que la discusión acerca de la «vida bienventurada» se termina por un himno a la Trinidad, cantado por Mónica, la cual sabía muy bien que ese himno era una «canción de guerra». También Le Blond nos ha hablado de "conversiones de san Agustín» ${ }^{49}$. Y todavía se queda corto en su visión; no profundiza bastante en la «evolución unitaria» de Agustín en el tiempo y en el espacio, desde la lectura del Hortensio, y quizá aún antes. Agustín dedica sus entretiens de Casiciaco a sus amigos Romaniano, Manlio Teodoro, Zenobio, y dirige una carta a Hermogeniano. Son los amigos de Milán, con los que ha sostenido discusiones filosóficas, y que quizá lamentan su ausencia: sin duda quiere demostrarles que sigue siendo el mismo, pero un poquito más aún de lo que ellos podían imaginar. Alipio no quería que se mencionase el nombre de Cristo, como luego Nebridio se molestará porque Agustín se deja arrastrar por la caridad cristiana. Todo eso indica que Agustín era más profundo de lo que sus amigos sospechaban; pero en su obstinación no se deja desviar de su ruta interior, de seguir su ley interior.

Agustín, convertido, era un cristiano especial. No era un «viejo cristiano», sino un «converso». Los viejos cristianos tenían que considerarle con cierto recelo: no era un cristiano como su madre, ni siquiera como Manlio

47. De Ordine, II, 20,52 PL 32,1010.- Ese alto bien es ya conocido: Dios y el alma. Solil. I, 2,7 PL 32,872.

48. BROWN, P., l.c., p. 111.

49. Le Blond, J.M., Les conversions de St. Augustin, Paris 1950. 
Teodoro, o como el obispo Ambrosio; tampoco era un monje como los que rezaban y ayunaban en los monasterios italianos. Si de algo le servían sus lecturas platónicas, era para confirmarle de la excelencia de buscar la verdad y de la facilidad de encontrarla en el estudio, en la contemplación y en la religión entendida como un misterio (ética, culto y castidad). El mismo Agustín define su postura: «nunca me separaré de la autoridad de Cristo, pues no la hallo mayor. En cuanto a la razón, confío en que iré hallando en el platonismo doctrinas que no repugnen a nuestros misterioz» ${ }^{50}$. Hallamos, pues, un sentido de continuidad y un propósito de continuidad, como dice Peter Brown, tanto más sorprendente cuanto que ya había oído hablai a Ponticiano acerca de los monjes en Oriente y en Occidente. Eso significa que él no es un «monje» como los otros, contentos con su ascetismo y en franca ruptura con el mundo clásico. Agustín, lejos de ver la necesidad de esa ruptura, se niega a participar en ella. Tampoco se identifica con el grupo neoplatónico de Milán, sino que es sólo fiel a sí mismo, a sus profundas raíces: «éstas sólo se revelarán diez años más tarde en las Confesiones de Agustín, obra de profunda autenticidad psicológica, más bien que en las obras formales y literarias del tiempo de su conversión. En estos escritos formales Agustín escribía como figura pública a otros hombres públicos; era un profesor retirado, y así alega su enfermedad como razón de su retiro... y pasa en silencio la escena del jardín de Milán. Y sin embargo, sólo en esa escena podemos adivinar la radical reorientación que se estaba produciendo en Agustín. Aquí se tocaban sus profundidades, que tenían escasa relación con su vida pública como hombre de letras: se trataba de la naturaleza de su dolorosa relación con las mujeres y, por cierto, su más íntima relación con su madre» ${ }^{51}$. Para no incurrir en contradicciones, diremos que ambas cosas son compatibles: una fidelidad a sí mismo que es ley, sentido y propósito de «continuidad», y una reorientación o reajuste de las perspectivas hacia Cristo, sin rupturas y sin gestos teatrales.

Agustín definirá su nueva situación como christianae vitae otium, y en ese sentido desarrolla Peter Brown la biografía del Santo. Esto es un nuevo error, que está en contradicción con la lucha encarnizada que Agustín declara al maniqueísmo, y del afán apostólico y misericordioso con que trata de desengañar a sus ex-correligionarios. También Brown se deja al fin engañar por el método de Agustín: en el mostrador, artes liberales, pero en la trastienda religión y teología. Y eso que advierte que algunos cristianos han reprendido a Agustín, estimando que ese método puede engañar a muchas gentes ${ }^{52}$.

50. «Sacris nostris» C. Acad. III, 20,43 PL 32,957. En el fondo tiene razón Brown, al calificar esa postura de «revolución» (BRown, l.c., p. 113).

51. Brown, l.c., p. 114.

52. Me benevolentissime monuerunt ut communem loquendi consuetudinem non desererem. De Gen. 'C. Manich. I, 1,1 PL 34,173. 
Sólo así se comprenderá la estancia en Casiciaco. No se trata ya de una platonópolis, y tampoco de un «monasterio laico» de los que se estaban fundando en Occidente. El otium liberale era sólo aparente y circunstancial, provisional. Se discutía acerca de la vita beata, pero Alipio iba desde Casiciaco a la metrópoli andando sobre la nieve. Se discutía acerca del Orden, replicando a un poema de Zenobio, pero se rezaban los salmos con un fervor que hacía derramar a Agustín abundantes lágrimas. Agustín hacía los honores a la «Filosofía», pero pensaba en los maniqueos, y unas veces se encoraginaba contra ellos, y otras los compadecía: deseaba que estuvieran viendo su corazón cristiano. Casiciaco no tenía pues sentido ni valor en sí mismo, sino dentro de un plan futuro. Se vivía esperando. Los competentes volvieron a Milán, y se bautizaron en la noche del 24 al 25 de abril del año 387 . Luego emprendieron el camino de vuelta, con la diligencia que se había llevado a la concubina de Agustín hacia el África. La guerra provocada por el tirano Máximo detuvo a los viajeros en Roma. En vano esperaron en Ostia Tiberina una ocasión para embarcarse. Mónica murió y los africanos (Agustín, Alipio, Evodio, quizá Nebridio, Adeodato, quizá Romaniano) tuvieron que esperar en Roma el fin de la guerra y la apertura del mar para regresar a Cartago. Sin embargo, ya aquí comenzó a revelarse el plan monástico de Agustín, una milicia al servicio y utilidad de la Iglesia, ordenada ante todo a combatir el maniqueísmo, símbolo de todas las herejías.

\section{Tercera etapa}

La suerte estaba echada. Agustín, Alipio, Evodio, Adeodato, y en esperanza Nebridio, pertenecían ya al grupo de los «siervos de Dios». Tal denominación era un tanto genérica en una sociedad en que abundaban los tipos extravagantes de todo linaje, cínicos, maniqueos, egipcios, filósofos, monjes; pero el grupo era fácilmente identificado por otros. Nadie hubiera confundido al grupo con un cenáculo de filósofos, o con una partida de aventureros. En Ostia Tiberina Agustín acompañó a su madre hasta la tumba, y luego se retiró a Roma a esperar. Allí escribió un ensayo Sobre la inmortalidad del alma y otro Sobre el crecimiento del alma. Quería sacar partido de sus lecturas platónicas, pero no quedaba satisfecho del resultado ${ }^{53}$. Y no podía ser de otro modo, dada su falta de preparación en materias de fe religiosa y sus vacilaciones en los problemas fundamentales de la filosofía griega.

Pero entre tanto emprendió una empresa que nos revela su autenticidad y su identidad. Aparece ese Agustín auténtico, que el platonismo nunca pudo sustituir ni encubrir, ese Agustín que se revela en sus rasgos característicos, y

53. Dixerunt haec quantum dicenda esse judicaverunt, magnae quaedam et incomparabiles animae, quas etiam vidisse ac videre ista credimus. De quant. Ant. 33,76. 
es el Agustín en lucha perpetua con el maniqueísmo. Ahora tenía motivos para ocuparse de él, pero hemos de agradecer y estudiar tales revelaciones. Por de pronto, en Roma volvió a ver a Constancio, el cual le había hospedado durante su anterior estancia en Roma. Más tarde nos dirá Agustín que se había convertido al cristianismo, quizá gracias al mismo Agustín. Lo cierto es que por Constancio pudo comprobar lo que ya había oído en Milán, a saber: que los maniqueos habían hecho también un ensayo de "vida común», y que ese ensayo había terminado en un rotundo fracaso, a pesar de que se había escrito para él una Regla según la Epístola de Mani ${ }^{54}$.

¿Qué razón movió a Agustín a escribir un libro de moral, y cuál es el auténtico carácter del mismo? Por de pronto, el libro no puede desligarse de la historia anterior de Agustín. Por el comienzo del libro, podemos saber que ha sido publicado algo más tarde, ya en África, cuando los lectores conocen otros libros en que Agustín refuta las objeciones maniqueas contra la Biblia. Cuando lo publica, tiene clara conciencia de que se trata de un argumento apologético, tal como lo utilizaban los maniqueos: la castidad y la abstinencia demuestran la verdad de una doctrina. Agustín no discute el valor filosófico del argumento, sino la realidad de los hechos. ¿Dónde están la auténtica castidad y la auténtica abstinencia, y qué es lo que demuestran? Tal deberá ser el sentido y el valor del libro de Agustín. El libro tratará, pues, de vita et moribus, y ante todo del concepto exacto de «virtud». Podría estar escrito muy bien para Constancio, su bienhechor, en su camino hacia el cristianismo ${ }^{55}$.

54. Dixi quae ipse compererim, cum in ea essem civitate ubi ista commissa sunt. Romae autem me absente quid gestum sit, totum longum est explicare. Dicam tamen brevi. Eo enim res erupit, ut occulta esse non posset (nobis) absentibus; et ego quidem postea Romae cum essem, omnia vera me audisse firmavi; quamvis tan familiaris et mihi probatus, qui praesens erat, ad me rem pertulerat, ut omnino dubitare non possem. De Mor. Eccl. II, 20,74 PL 32,1376. Los hechos que aquí se mencionan mantienen la continuidad de la autenticidad agustiniana. Estando Agustín en Roma infunde en su anfitrión Constancio cierta desconfianza hacia el maniqueísmo, y concretamente hacia el comportamiento de los «perfectos». Constancio los defiende, pero se molesta de que siempre le objeten los mismos abusos de sus electos. Cuando Agustín va a Milán, Constancio planea su ensayo de «vida común» en una vivendi regula de Manichaei Epistola. Comprobado el fracaso Constancio se desilusiona, da la razón a Agustín y le escribe a Milán, narrándole la pintoresca historia. Agustín cree a Constancio, pero probablemente ya había discutido con él el argumento «moral»: una doctrina debería poderse comprobar con la práctica. Y entonces el «plan de vida común», que proponen los africanos amigos de Agustín, del que ya hemos hablado, estaría bajo la influencia del maniqueísmo. Sin embargo, entretanto, Agustín se ha confirmado en su aprecio de la filosofía, y su propósito de combinar la razón con la fe (ese había sido su ideal maniqueo), se estabiliza juntamente. Quiere ser uno de los perfectos, un cristiano total, y no un usemicristiano" como llaman los maniqueos a los cristianos mundanos. El monacato viene a ofrecerle la visión exacta de lo que él desea. Al mismo tiempo, su «milicia cristiana» tiene ya un objetivo concreto: el maniqueísmo. Es preciso combatir el maniqueísmo que tanto le ha desilusionado. No se trata de combatirle con iracundia y cólera sino sabiendo cuán fácil es caer en el error. Por eso, al volver a dialogar con Constancio, idea su libro Sobre las costumbres de la Iglesia.

55. Sanari eos potius, si fieri potest, quam oppugnare volo. De Mor., I, 1,2 PL 32,1311. 
Por lo general pasamos frívolamente sobre ese libro, que es una de las claves para reconocer a Agustín. Consignemos, pues, ante todo, que su ideal es reunir en el hombre las dos fuentes de información, la fe y la razón, la autoridad y el libre examen. Durante muchos años él ha meditado sobre el problema del método y ha llegado a esa conclusión. Según el orden, la autoridad precede a la razón. Pero como los maniqueos piensan y hablan «contra el orden», Agustín se acomoda a su modo de ser y comienza por la razón. No nos interesa la discusión teorética de momento, a no ser por el concepto de virtud como rectitud. Pensaba Agustín que virtud es la rectitud de la mirada mental frente a su objetivo. Esa noción es griega, ya que supone que el vicio es un error; supone que se trata de un tiro al blanco, y el pecado es un fallo, un error (amartano); supone la metáfora de la visión, en la cual, la mirada debe ser dirigida rectamente al objeto, para verlo bien. Por lo mismo, todo depende ahora del «objeto». Desde el momento en que ese objeto es para Agustín el Dios verdadero, la mirada del alma debe dirigirse al Dios verdadero (intención), para que haya «virtud» auténtica; en otro caso hay desviación, vicio constitutivo, o vicio de construcción, error, fallo. Esto no significa una «reducción de todas las virtudes a la caridad», como suele decirse, ya que eso es absurdo. ¿No es absurdo decir que, según san Agustín, la limosna y la virginidad son la misma cosa? ¿No es absurdo decir, como lo hacía Rohmer, que para Agustín se trata de una moral de intención, es decir, que la blasfemia, la mentira, el asesinato, el adulterio, son buenos, si se hacen con buen intención? No. No se trata de eso.

Se trata ante todo del «objeto». Agustín juega noblemente la carta cristiana. La moral ya no pertenece para él a la física, como en Grecia, en que el alma es un objeto de la física y no existe una libertad auténtica. En Grecia, la mula que mata a un hombre de una coz comete un asesinato indiscutible. En el cristianismo nadie comete un asesinato, si no sabe lo que hace, o no puede evitarlo: el pecado supone libertad auténtica. Por lo mismo, la moral es arrancada de su campo «objetivista» hacia un terreno «subjetivista», por lo que toca al sujeto, que ahora es la persona libre y consciente. Pero eso no cambia en nada la moral llamada «objetiva», en la cual cada virtud se define por su «objeto formal»: Agustín respeta esa nomenclatura que encuentra en Cicerón y no piensa cambiarla para nada. Sólo que, teniendo en cuenta lo dicho, toda virtud auténtica tiene que reunir dos propiedades: 1) ser libre; 2 dirigirse al objeto verdadero. Tal es el sistema que Agustín comienza a desarrollar en este Libro de las Costumbres, al proponer la caridad como «común denominador» de todas las virtudes auténticas: rectitud verdadera ${ }^{56}$.

Agustín ha corregido a Cicerón en el De Finibus bonorum, al recurrir a la Biblia, que los maniqueos admiten: el fin de todos los bienes es el primer man-

56. Sequere Deum... Sed quo pacto sequimur quem non videmus?... Ergo nobis illa opacitas auctoritatis occurrat. Ibid. I, 7,11 col. 1315. Cfr. I, 2,3 col. $1311 \mathrm{~s}$. 
damiento: amarás al Señor, tu Dios. También corrige Agustín el «modo de amar», pues hay que amar a Dios «con todo el corazón, alma y mente». De esta manera, queda ya fijada la orientación de la moral ${ }^{57}$.

Veamos ahora la información y el juicio que Agustín emite sobre el monacato que ha podido conocer, ya que pretende oponer un argumento cristiano al argumento maniqueo, basado en las costumbres. Mantiene viva la tensión maniquea entre la libido y la virtud. El argumento cristiano alega que entre los cristianos, se dan no sólo la castidad y la abstinencia, sino incluso el deleite de la soledad ${ }^{58}$.

Agustín comienza por los anacoretas de Egipto. Es claro que los maniqueos conocen los hechos, sin duda porque en los últimos años se ha hablado en Roma mucho acerca de esto; anteriormente Agustín nunca había oído hablar de los anacoretas de Egipto. Agustín celebra su vida angélica pero confiesa que muchos estiman que esos monjes han abandonado las cosas humanas más de lo conveniente. Destaca, pues, su oración y su ejemplo, como formas de apostolado. Pero si la vida de los anacoretas parece exceder nuestra capacidad de tolerancia, la vida de los cenobitas es un espejo terso. Aunque las fuentes de información pueden ser diferentes, tengamos bastante con las referencias de san Atanasio en su Vida de Antonio, en las Epístolas de san Jerónimo, que corrían por Roma, y en las informaciones directas de los monasterios milaneses y romanos, que en ese año daban no poco que hablar, en pro y en contra.

La vida cenobítica exige el desdén y el abandono, no del mundo, sino de los atractivos (illecebrae) del mundo, la vida común, casta y santa, la oración; la lectura, la discusión o diálogo. Esto, de entrada. Agustín llevado de su afán apologético, hace un resumen idealista de sus informaciones. Los cenobitas, no se envanecen con el orgullo, no discuten por pertinacia, no obran por envidia. Son modestos, verecundos, tranquilos, ordenan al Dios verdadero una vida llena de concordia y de fervor, como un don o sacrificio gratísimo que le ofrecen, pues de él recibieron la capacidad de vivir de ese modo. Nadie posee nada propio, nadie sirve de carga a otro. Con sus manos se ganan el sustento, sin que su mente se separe de Dios. Entregan las obras terminadas a los decanos o prepósitos (denis praepositi) para que nadie tenga que cuidarse de su

57. Ad id omnia consilia nostra referenda. Bonorum summa, Deus nobis est. Deus est nobis Summum Bonum. Id. I, $8,13 \mathrm{col}$. 1316. Si virtus ad beatam vitam nos ducit, nihil omnino esse virtutem affirmaverim, nisi summum amorem Dei, Id. Id. I, 15,25 col. 1322; Quadripartita virtus, ex ipsius amoris varios affectu dicitur. Ibid. El amor añade pues un afecto especial, pero se conserva y mantiene siempre el «aspecto formal».

58. Merito apud Te (Ecclesiam) visum est, quam sit sub Lege operatio vana, cum libido animum vastat et cohibetur penae metu, non amore virtutis obruitur. Merito tibi tan multi hospitales... usque adeo Dei amore flagrantes, ut eos in summa continentia atque mundi huius incredibili contemptu etiam solitudo delectet. Ibid. 130, 64 col. 1337; Accipite, Manichaei, perfectorum christianorum... castitatem, mores et continentiam singularem. Id, I, 31,65 PL 32,1337. 
cuerpo, atendido por los prepósitos. Estos son los que ahora reemplazan a los administradores o magistrados pitagóricos. Los prepósitos a su vez, dan cuenta de su gestión al Padre, o Superior. Tenemos, pues, una organización paramilitar constituida por decurias, a cuyo frente hay un decano o Prepósito, y al frente del Monasterio hay un Padre. Hay además otros funcionarios específicos que también se llaman prepósitos, por estar al frente de las diferentes oficinas, librería, sastrería, zapatería, etc. El Superior o Padre deberá distinguirse no sólo por su santidad, sino también por su sabiduría, para atender a los monjes, ya que goza de la mayor autoridad, y ellos le obedecen con la mejor voluntad.

Se ayuna diariamente. Al fin del día se reúnen para escuchar la conferencia del Padre; quizá se reúnen unos tres mil para escuchar a cada Padre. Evidentemente se trata de Egipto, o del cercano Oriente. Luego toman el alimento conveniente, según la capacidad de cada uno. Sobra dinero para atender a lo necesario, pues se trabaja mucho y se como poco; pero ese dinero se distribuye a los indigentes, lo mismo que el sobrante de los productos que son enviados (sin duda por el Nilo) en naves a las regiones pobres.

Una descripción semejante revela el monacato femenino. Las monjas hacen los vestidos que utilizan los monjes, y éstos pagan con lo que las monjas necesitan para su alimentación. Del intercambio se encargan los ancianos mejor probados ${ }^{59}$.

La descripción, simplificada e idealizada, tiende a aceptar el desafío maniqueo, planteando el problema moral de un modo radical, $q$ bien obligando al adversario a comprobar mil detalles en los que también los maniqueos saldrían perjudicados, por lo que más bien les conviene callar y aceptarlo todo sin discusión, reservándose tan sólo la «interpretación». Por lo mismo, Agustín busca especialmente la interpretación. Para ello, no se detiene en la descripción de los anacoretas y cenobitas, sino que continúa su descripción, tratando de presentar un problema «eclesiástico» o eclesiológico, que refleje «las costumbres de la Iglesia», de la que los monjes son un exponente de perfección. Hay que evitar, pues, dos defectos: 1) el pensar que las costumbres de los monjes no son un exponente de la perfección moral de la Iglesia, por lo que su inmoralidad sería inmoralidad de la misma Iglesia; 2) que la Iglesia no tiene otras buenas costumbres que las que exhiben estos individuos «profesionales de la santidad», por decirlo así.

Agustín aduce, pues, la experiencia de los obispos, presbíteros, diáconos y ministros de la Jerarquía. Estima que su virtud es más maravillosa y laudable, ya que florece en un ambiente mundano y difícil. No trabajan con los sanos sino con los enfermos, a los que desean curar. Es preciso tolerar la Severo.

59. De Mor., I, 31,65-32,69 PL 32,1337-1339. Agustín no conoció los Diálogos de Sulpicio 
pestilencia, antes de superarla. Mientras los monjẹs habitan allí donde se vive, estos agentes apostólicos viven donde se aprende a vivir.

Cuando Agustín termine su descripción, tomada sin duda de segunda mano, y dirigida contra las jactancias de los maniqueos, nos da cuenta de su experiencia personal. Parece extraño, que no nos hable de un «monasterio» sino de un «diversorio» en Milán. La razón parece ser que el término «monasterio» se usaba todavía para designar la celda de un monje (monachos), aunque estuviese construida junto a otras celdas semejantes de otros monjes. En ese mismo tiempo se generalizó el uso de la palabra para designar un "cenobio», mientras que antes el cenobio construido en los suburbios de una ciudad se llamaba «diversorium». San Jerónimo había estimado desdeñosamente que esos supuestos monjes eran seudomonjes. Agustín opina todo lo contrario, y ya vamos viendo por qué. "Yo vi un diversorio de santos en Milán. Eran numerosos, y los presidía un presbítero, varón óptimo y doctísimo. También he visitado en Roma muchos otros, en los que los Superiores con gravedad, prudencia y divina ciencia presiden a los que viven con ellos en la caridad, santidad y libertad cristianas. Nadie sirve de carga a otro. A imitación del Oriente y atentos a la autoridad del apóstol Pablo viven de su trabajo manual. Supe que muchos resisten ayunos increíbles, no según el ayuno usual (cenar a la puesta del sol) sino durante tres días arreo. Y eso mismo acontece con las mujeres... vírgenes y viudas, preparadas y capacitadas, no sólo para instituir y componer las costumbres, sino también para instruir las inteligencias ${ }^{60}$. Mientras san Jerónimo se burla de los que dicen omnia munda mundis (Tit 1,15), Agustín es uno de los que lo repiten y toman muy en serio. Porque ha realizado en el ascetismo la misma operación que ha realizado en la moral, a saber: todo depende del Objeto Último o Bien Sumo, al que tiene que ser dirigida la flecha de la intención humana, y todo depende de la libertad humana para que sea virtud lo que puede ser, como en el caso de los maniqueos (o de los romanos), un "espléndido vicio» ${ }^{61}$. El desdeñar el vino o la carne, como si fuesen «intrínsecamente malos», es calificado de estulticia, y celo indiscreto. La caridad es la que es mantenida y cantada, cultivada y honrada, como si fuese Dios mismo ${ }^{62}$.

Hay otras revelaciones significativas. El valor del argumento moral depende de la relación o conexión que exista entre las costumbres humanas y los principios que las animan. Por eso Agustín acepta el valor del argumento en sentido «positivo»: las «buenas» costumbres prueban la veracidad y fuerza de

60. De Mor. Eccl. I, 33,71 PL 32,1339s.

61. Meminerunt omnia munda mundis et non quod intrat in os vestrum vos coinquinat, sed quod exit (Mt 15,11). No se mira, pues, a la impureza de los alimentos, sino a la de la concupiscencia y al cuidado de la caridad fraterna: el virus que emponzoña moralmente la vida está, no en los alimentos, sino en el alma. También aquí los más fervorosos deberán adaptarse a los débiles. Id. I, 33,71 PL 32,1340s.

62. Id. I, 33,73 PL 32,1341 . 
una doctrina. Pero ¿qué decir de las «malas» costumbres, que son claras tanto entre los cristianos como entre los maniqueos? Por de pronto, hay que distinguir. Las costumbres «malas» tendrían el mismo sentido y valor que las «buenas», si se demostrase que son el resultado causado o motivado por las doctrinas y principios. Pero nada prueban, si precisamente van contra los principios y doctrinas. El cristianismo puede alegar que produce buenos cristianos: las costumbres de esos cristianos tienen valor y sentido. Pero si alguien se llama «cristiano» y obra contra los principios y doctrinas cristianas, tales costumbres nada prueban contra los principios y doctrinas cristianas. Lo mismo podría decirse del maniqueísmo, y eso es lo que pretende comprobar san Agustín. Pero entonces, aparece la originalidad del mismo Agustín: su monacato no puede concebirse sin el maniqueísmo, sin la crítica maniquea.

El cotejo o desafío se plantea en estos términos: he aquí lo que yo presento en los buenos cristianos, y concretamente en los cristianos llamados «perfectos»; criticadlo, si podéis, y comprobaréis «la diferencia entre un perfecto cristiano y un perfecto maniqueo, entre las sirenas de la superstición y el puerto de la religión» ${ }^{63}$. Tratándose de un desafío, es preciso escuchar al maniqueo que acusa a los cristianos: 1) hay gente que profesa el nombre de cristiano, pero no conoce ni muestra la virtualidad de su religión; 2) hay «cristianos» entregados a la libido, de manera que olvidaron lo que han prometido a Dios; 3) hay quienes adoran los sepulcros de los muertos (mártires) y las pinturas; 4) algunos cristianos renunciaron de pico a este siglo, pero viven oprimidos por su pesadumbre y gozosos de ello. No es extraño que haya cristianos malos en tan grande muchedumbre de gentes. Pero otra cosa son los maniqueos: no pueden mostrar cuántos «perfectos» de los suyos cumplen sus propios preceptos; pero además, los mismos preceptos son vanos, nocivos y sacrílegos ${ }^{64}$. Agustín acepta las acusaciones contra los cristianos, y por lo mismo no pertenece a esos cristianos rutinarios, que creen que todo va bien dentro de su religión. Agustín muestra aquí su afán reformista, revelando que desde la raíz de su ser es un reformador, aunque haya comenzado por sí mismo, y que su monacato es un ensayo de reforma. Sin ese rasgo fundamental, el monacato de Agustín no tiene ni sentido ni valor. Por eso hemos dicho que no puede ser comprendido sin el maniqueísmo y frente al maniqueísmo. Es un desafío con el maniqueísmo, aunque muchos detesten hasta el nombrar el maniqueísmo. Agustín en su maniqueísmo ha denunciado con frecuencia los vicios cristianos, $y$ ahora no puede negar que existen, que son reales; tampoco puede callarse o aceptarlos como si fueran virtudes. Por honradez humana, se ve precisado a combatir a sus antiguos amigos y correligionarios, si no los puede convencer y convertir. Sin esto, nadie entenderá auténtícamente a Agustín.

63. Id. I, $24,74 \mathrm{PL} 32,1342$.

64. De Civ Dei. XXII, 8,3 PL 41,762 . 
No terminan aquí las revelaciones significativas. Al fin Agustín se embarca y llega a Cartago, muy cambiado (alii redivimus), dispuesto a realizar su propósito, al frente de una milicia christiana, muy escasa, antes de «cerrarse el mar» el año 388. "La pequeña comunidad podía significar muchas cosas para mucha gente», desde luego. Pero quien pensara que se trataba de un cenáculo de filósofos, como dice Brown, o como piensa que decía Nebridio, se engañaría de medio a medio. En efecto, Agustín y Alipio se hospedan en Cartago, en su paso hacia Tagaste, en casa de Inocencio, un cristiano ejemplar ${ }^{64 b i s}$. Allí se encuentra con algunos personajes, entre los que cabe destacar a Aurelio, el futuro arzobispo de Cartago. Las conversaciones recaen sobre la reforma de la Iglesia, concretamente sobre los «vicios» que se observaban entre los cristianos y muy especialmente dentro del clero. Agustín podía aportar su experiencia, pero tenía mucho que aprender, e incluso encontraba una nueva visión de la situación cristiana en África, que anteriormente no le había interesado. Porque ahora al enemigo número uno, que era el maniqueísmo, se juntaba el enemigo número dos, que era el donatismo nacionalista. Preocupaba la falta de vocaciones clericales y la desorientación de los católicos. La «utilidad de la Iglesia», a cuya causa quería Agustín dedicar su pequeña milicia, tenía por delante una empresa gigantesca que parecía imposible ${ }^{65}$.

Agustín no renuncia a su empeño de concordar la fe con la ciencia, y por lo mismo mantiene su ideal. Habla de artes liberales, pero predica religión y teología. De ese modo, compone un «Pentateuco Antimaniqueo», como dice san Paulino de Nola. De momento el donatismo no aparece como enemigo declarado, pero la preparación y capacitación de Agustín está ya probada frente al maniqueísmo. Porque el donatismo cometerá el mismo error del maniqueísmo: acusar a los católicos de impuros y pecadores, áireando el argumento moral, buscando no la reforma, sino la condenación de los acusados. De ese modo, Agustín funda en Tagaste un auténtico monasterio, habitado por una comunidad de monjes. Esta comunidad se diferencia de la vida monástica que Agustín ha conocido en Italia y en la literatura por varias razones: 1) es una comunidad apostólica, es decir, no separada del mundo ni de la Iglesia, sino «al servicio y utilidad de la misma Iglesia; 2) es una milicia espiritual activa, que se ajusta al postulado anterior; 3) lejos de renunciar a la cienci i, trata de servir a la Iglesia conjugando la fe con la razón, y desarrollando ambas para practicar el apostolado que Agustín estima entonces ser el más oportuno o necesario: apostolado de la inteligencia, de la propaganda, de la acción y discusión intelectuales, de la pluma, de la controversia pública, de todo lo que pueda contribuir a la conversión del hereje o a su derrota; 4) es una orga-

65. Ep. 22 PL 33,90. Agustín tendrá que esperar aún algunos años para recordar a Aurelio las antiguas conversaciones sobre la reforma de la Iglesia, y para iniciar ese aspecto oficial de la reforma. Entretanto va a Tagaste, organiza un "diversorio», que ya se llamará monasterio, y vende el resto de sus posesiones, para servir enteramente a Dios. 
nización de caridad; eso significa que está al servicio de los laicos, mientras estos se encargan de ofrecer a los monjes la ayuda material (comercium caritatis); 5) corre el peligro de descuidar el trabajo manual, por atender al trabajo intelectual y espiritual; 6) Agustín no sabe aún hasta dónde puede llegar la conexión o unión entre el monasterio y la Jerarquía eclesiástica, si bien el monasterio aspira a una reforma, y en ese sentido favorece todos los intentos de reforma de la Jerarquía ${ }^{66}$.

Es una puerilidad creer que Agustín se dedicaba a estudiar problemas «filosóficos», y que para ello vivía en una casa con los que se comprometían a servir a Dios, a fuerza de ayunos, oraciones, buenas obras de apostolado, meditando en la ley del Señor y consignando por escrito para los presentes y los ausentes lo que Dios le iba revelando en la meditación y en la oración, dedicándose a la predicación y a la escritura ${ }^{67}$, como dice Posidio. Sería un modo bien extraño de dedicarse a los problemas fílosóficos, si leemos el «Pentateuco

66. El año 1961 publicó G. Folliet en la Colección Studia Anselmiana (S. Martin et son temps, Roma 1961, pp. 25-45) un artículo titulado Aux origines de l'ascetisme et du cenobitisme africaine. Después de los años transcurridos desde entonces, el artículo es todavía más sorprendente que en su aparición. No se sabe por qué en el título van unidos el ascetismo y el cenobitismo, siendo cosas tan diferentes; no se sabe por qué, para explicar un cenobitismo, hace falta explicar la historia de un ascetismo que se remonta a los orígenes de la humanidad; en África o en cualquiera otra parte; no se sabe por qué aparece un interés en demostrar que antes de Agustín hubo en África «monasterios», pues no hay prueba ninguna; no se sabe por qué se niega que Agustín fundase en Tagaste un «monasterio»; eso resulta poco serio, pues el mismo Folliet dice candorosamente: «tendremos una idea, lo más exacta posible de lo que era el ascetismo africano alrededor del año 390, antes de que Agustín estableciese su primer monasterio» (l.c. p. 34); no se sabe por qué se omiten todos los antecedentes de Agustín, el contexto de su fundación, y en cambio se dedica el interés a las vírgenes, viudas, continentes y ascetas; no se sabe por qué el autor se deja engañar por apariencias, hablando del ocio filosófico de Tagaste, mientras Nebridio protesta porque no se mantiene ese ocio, sino que Agustín se dedica al apostolado activo; no se sabe por qué no se precisa el significado del término monasterio, que de por sí significaba la celda de un asceta, mientras posteriormente pasó a significar un cenobio; no se sabe por qué Nebridio, como si fuese un desconocido, es presentado como «un siervo de Dios», que vive en castidad y continencia, (Confess. IX, 3,6) y no se dice que a pesar de su simpatía y del cariño que Agustín le profesaba, nunca se determinó a dejar su casa y seguir a Agustín a servir a Dios, pero «en el monasterio de Tagaste», y no en su casa; no se sabe por qué se afirma que sólo Agustín renunció a sus bienes, como si supiéramos que los demás no renunciaron, lo cual sería injurioso para Alipio, que en esta materia era más riguroso que Agustín mismo; aparte de que el retener cosas propias no era en ese tiempo ningún inconveniente, como lo vemos en S. Jerónimo, si se vivía con cierta independencia; no se sabe por qué se afirma que Agustín escribía sobre problemas «filosóficos», y no sobre problemas «religiosos»; no se sabe con qué derecho cuenta el autor para afirmar: «por tanto, reservaremos el término monasterio para designar la fundación de Hipona» (Id. p. 39); podía haber reservado ese término para la fundación de Cluny; no se sabe por qué el testimonio de Posidio es interpretado con tanta libertad: «Agustín, según Posidio, vivía dentro de la misma casa durante tres años con los que se habían unido a él y con ellos vivía para Dios, en ayunos, oraciones, y buenas obras, meditando de día y de noche en la ley del Señor». ¿No es eso lo que llamamos un monasterio? No se sabe por qué hay interés en interpretar a Agustín tan mal como a Posidio.

67. Posidio, Vita Augustini, 3, PL 32,36. 
Antimaniqueo». Pero no es menos pueril pensar que Agustín se convirtió en monje precisamente en el mismo momento en que, a nuestro juicio, «dejó de serlo». Veamos. Había en Hipona un funcionario (agens in rebus), que había oído hablar de la fama y doctrina de Agustín, el cual vivía en Tagaste; declaró que desearía ver al Maestro y que estaría pronto a renunciar a la ambición y al atractivo del mundo, si pudiera oírle; se lo contaron al Santo, y éste fue a $\mathrm{Hi}$ pona a ver al funcionario. Sin embargo, el funcionario dio largas al asunto. $Y$ un día en que Agustín asistía de incógnito al culto, fue llevado al obispo. Agustín lloraba, pero no hubo remedio: fue ordenado de presbítero y entonces fundó un monasterio en un huerto que le cedió el obispo ${ }^{68}$. Esto es lo que cuenta sucintamente san Posidio. Gracias a Dios, tenemos una información más precisa.

Pero no perdamos la dirección profunda y principal. «La tensión entre católicos y maniqueos era particularmente aguda en África: ellos eran los «herejes» por excelencia. No es sorprendente que los libros de Agustín contra los maniqueos cobraran un sentido más decisivamente «eclesiástico» en su ambiente... Así, el hecho de que Agustín y sus amigos en Tagaste fueran exmaniqueos, que planteaban enérgicamente una solución para el problema maniqueo, debió cobrar extraordinaria importancia a los ojos de las autoridades de la iglesia africana» ${ }^{69}$.

La correspondencia con Nebridio toma un cariz fascinante, porque va abriendo un abismo entre ambos amigos. Nebridio se ha quedado estancado en el pasado y no se incorpora al mundo «nuevo»: quiere que Agustín hable de problemas filosóficos, pero Agustín se niega a satisfacer una «curiosidad» que ya considera como puerilidad. Hay platónicos, que se han incorporado ya al cristianismo: los hay, que se mantienen estancados en sus concupiscencias, los hay que en su «curiosidad» terminan por entregarse a la teurgia y otras extravagancias diabólicas propias del paganismo. Para Agustín el platonismo sólo es aceptable, si es preámbulo del cristianismo ${ }^{70}$. El libro De Vera Religione es un solemne mentís de Agustín a todo intento de interpretar la Casa de Tagaste como una Academia y no como un Monasterio, que es una Ciudadela.

Mantengamos sin embargo el término «evolución», ya que Agustín está evolucionando visiblemente. Sus afanes «contemplativos» y sapienciales van cediendo a las necesidades apostólicas. Si antes parecía un desarraigado, un perpetuo "emigrante», ahora va echando raíces en la tierra, asentando los pies vigorosamente en su suelo. $\mathrm{Y}$ en ese momento mueren dos de sus seres más

68. Ibid. La puerilidad consistiría en creer que Agustín fue a Hipona a reclutar un carididato para un monasterio que pensaba fundar quién sabe cuándo y quién sabe cómo, puesto que Agustín tomaba precauciones para no ser conocido o identificado.

69. BRown, l.c., p. 134.

70. De Vera Relig. 4,7 PL 34,126. 
queridos: Nebridio y Adeodato. Agustín nada dice acerca de su dolor o de las reflexiones que la muerte de los suyos le despertó. Es claro que se había forjado quién sabe qué esperanzas sobre ambos, pero las dos esperanzas se agostaron de pronto sin sentido ni razón. ¿No sería esto un motivo para lanzarle a una vida más activa, a la acción directa? Algunos lo creen así ${ }^{71}$. Es curioso el cambio producido. Al principio Agustín estimaba que el visitar a Nebridio en Cartago era una traición a los que vivían con él ${ }^{72}$; «dos años más tarde, viaja hasta Hipona para reclutar a un candidato para un monasterio existente, y no para algún monasterio futuro, posible o futurible ${ }^{73}$. Agustín afirma luego que llevaba la intención de fundar un monasterio y que buscaba lugar para eso ${ }^{74}$. Esto parece crear alguna confusión que pudiera ser aprovechada para falsas interpretaciones. ¿Cómo hemos de concordar a Agustín con Posidio? El texto de Posidio es taxativo y no ofrece vacilación. En cambio el de Agustín, sí: podemos suponer que buscaba lugar para fundar un monasterio, y entonces hubiera visitado otros lugares y no sólo Hipona; a no ser que le hubieran secuestrado en su primera visita; podemos entender que visitó otros lugares, pues nos dice que sólo entraba en ciudades donde ya había obispo, por miedo a ser secuestrado; podemos creer a Agustín que dice que estaba buscando tiempo para estudiar más a fondo la Biblia, ut nobis otium ad hoc negotium posset esse ${ }^{75}$; o podemos suponer que Agustín, más tarde piensa en el monasterio del Huerto consecutive, esto es, tal como la fundación se efectuó, cuando él alegó que su uausencia de Tagaste podía ser dañosa para la iglesia de Cristo y para la utilidad a los hermanos y consiervos» .

Esa última interpretación es la que preferimos. Consideramos, pues, que tienen razón los que traducen el pensamiento de Agustín, afirmando que el Santo quería fundar en Hipona «otro» monasterio. Sólo que esa palabra «otro» es ambigua: puede significar que era otro, igual que el de Tagaste. o bien otro diferente del de Tagaste. Mejor es esta última interpretación, ya que se fundaba con nuevas experiencias, con nuevos estudios de la Biblia, con nuevas conexiones con el pueblo, con el clero, con el obispo, con una nueva conciencia pastoral, y una nueva responsabilidad jerárquica.

¿Se convirtió Agustín en un monje presbítero? Es un modo de hablar, ya que presbiterado y monacato son cosas diferentes. Agustín no había pensado en esto, ni lo había pretendido: por lo mismo, quedaba fuera de su concepto de monacato. Sin embargo había ideado éste con tal amplitud y profundidad, que todas las circunstancias, como signos de los tiempos, podían contribuir a

71. BRown, l.c., p. 135.

72. Hic sunt qui nec venire mecum queant, et quos deserere nefas putem. Ep. 10, I PL 33,74 .

73. S. Posidio, Vita, 3,3 PL 32,36.

74. Serm. 355, 1s, PL 39,1569s.

75. Ep. 21,6 PL 33,90. 
modificar y orientar el «principio de evolución», o ley interna de ese monacato, hacia objetivos nuevos, siempre posibles. Deberemos, pues, decir que el ensayo del monacato agustiniano terminaba aquí: el monasterio del Huerto era una cierta «novedad». Pero, dado el concepto de milicia al servicio y utilidad de la Iglesia, dado el ideal de unir la fe con la razón, dado el carácter apologético de la fundación, se abría delante de ese monacato un abanico de posibilidades, que las circunstancias deberían ir aplicando como auténtica voluntad o voz de Dios. Y esto fue lo que realmente aconteció, al convertirse el monasterio en seminario y palestra eclesiástica.

Ya desde el principio, Agustín había comunicado a Aurelio que una reforma no puede afrontarse directamente con el pueblo, con la masa de los cristianos, sino con los dirigentes del pueblo. Por eso, la reforma directa de las costumbres se refería tan sólo a tres o cuatro «vicios», que los maniqueos solían echar en cara a los católicos. En cambio, tal reforma debía dirigirse al clero. Ahora bien, una serie de circunstancias hacía difícil la situación de ese clero y su eficacia pastoral. La Paz de Constantino había traído como consecuencia la incorporación a la Iglesia de una gran masa de paganos y concretamente de dirigentes políticos, cuya cristianización era demasiado superficial. El clero estaba por lo general mal reclutado y mal formado. El cisma donatista traía como consecuencia una gran carencia de vocaciones y la triste necesidad de imponer la clericatura en formas tan extrañas como las que se usaron con el mismo Agustín. Era, pues, natural que Agustín se diera cuenta de que el monasterio podía ser la gran solución a muchos de estos problemas sociológicos, o científicos de la Iglesia. De un modo espontáneo, el monasterio estaba destinado a convertirse en seminario. Agustín fue ordenado en Hipona. Alipio en Tagaste; poco a poco, todos los viejos amigos de Agustín fueron ordenados de presbíteros y luego consagrados como obispos. Ellos a su vez, fundaron monasterios para reclutar y formar su clero ${ }^{76}$.

Este era el principio de una reforma a fondo. Agustín tuvo la pretensión de que el clero en su totalidad recibiese la influencia monástica, haciendo un fundamental "voto de pobreza», o algo semejante, que testificase ante el pueblo el desprendimiento y la sinceridad cristiana de los clérigos, empeñados en «seguir e imitar a Cristo». Los mismos obispos deberían solidarizarse con ese seguimiento de Cristo; de ese modo, la Iglesia podía mostrar al mundo su autenticidad e identidad cristianas. Una reforma tan profunda había de encontrar una tal resistencia, que sólo mediante la fuerza de la vida monástica podría ser superada. La experiencia mostró en la misma diócesis de Hipona hasta dónde quería llegar Agustín.

Pero había otro punto, que Agustín puso de relieve desde el principio. El clero debía renunciar a su apetito de dominio, deponiendo los modos dema-

76. Brev. Hipp. II, 19, Mansi, III, 922,924. 
siado humanos de ejercer la autoridad sobre el pueblo. Eso se lograría de dos modos. Ante todo, utilizando la Sagrada Escritura para mostrar al pueblo que se le impone la autoridad en nombre de Dios, y no en nombre del clero, eliminando así un clericalismo tan fácil como funesto. Y en segundo lugar, recurriendo al sistema de celebrar anualmente un Concilio "provincial», que se encargara de ir realizando la reforma de los vicios populares y de ir promoviendo la espiritualidad y el fervor cristianos. En todo caso, san Posidio testifica que Agustín dejó la reforma en marcha: dejaba a la Iglesia un clero suficientísimo, y los monasterios llenos de hombres y mujeres continentes con sus correspondientes prepósitos ${ }^{77}$.

Consagrado Agustín obispo de Hipona, fundó en su propia casa un «presbiterio», que pudiera denominarse un «cabildo de canónigos regulares»: eso era un simple desarrollo de la idea agustiniana, que organiza la diócesis. De ese modo, Agustín hubiera llegado a la reforma total de la Iglesia.

Era natural que, si para su obra necesitaba «nuevas teologías», la experiencia pastoral le proporcionaba esas nuevas teologías. Desde un punto de vista filosófico, era inevitable que aplicase al monacato la filosofía de la unidad, que planteaba en el De Genesi contra Manicheos: «La reunión de las aguas en un lugar es su formación, ya que toda forma ha de atenerse a la ley de la unidad. Y lo que llamamos unidad, es la misma energía de la forma». A esa suprema ley de la unidad se acomodan la ley de la verdad y la ley de la felicidad. Y es notorio que la unidad se logra mediante la caridad, que es la fuerza vital, que anima los organismos vivos. De ese modo, se constituye una mística, que finalmente será una Mística del Christus totus y juntamente una Mística de la Memoria Dei. El cisma donatista obliga a configurar ese tipo de mística agustiniana. Pero, del mismo modo, podríamos hablar de una filosofía o teología de la caridad, o mejor de una mística de la caridad, como lo han hecho algunos comentaristas. Finalmente, podríamos hablar también de una teología de Pentecostés, poniendo de relieve la pobreza, la caridad y la unidad, bajo la acción del Espíritu Santo, como lo hacen otros comentaristas ${ }^{78}$.

Caben muchas posibilidades, además de las que coyunturalmente fueron surgiendo. Pero hay que tener en cuenta que esos tipos de «teologías del monacato" no caracterizan exclusivamente al monacato agustiniano, ya que surgieron más tarde, como fruto de la reflexión sobre ese monacato ya constituido. Por eso, los comentaristas advierten sin cesar que tales «teologías» no son propias de monjes, sino comunes a todos los cristianos. Y así tiene que ser, si concebimos el monacato como un principio de reforma dentro de cada diócesis, ordenado a la utilidad de la misma diócesis. Hay que advertir

77. S. Posidio, Vita, 31 PL $32,64$.

78. S. Posidio, Vita, 5 PL $32,37$. 
también que, si bien pueden distinguirse varios tipos de «teologías del monacato", todas ellas no son sino aspectos de la teología de la Iglesia en general, como lo vienen demostrando estos comentaristas aludidos. Todo lo que nos ofrecen es común a los cristianos, pero sobre todo es común a todos los tipos de monacato, sin diferencia ninguna aparente. No pueden ser «definiciones» del monacato agustiniano. Son en realidad, desarrollos abstractos o dialécticos de la filosofía de Agustín.

Finalmente, sería mejor hablar de mística del monacato y no de teología del monacato. La razón es que no se trata aquí de especulaciones teológicas acerca del monacato, sino de experiencias vitalistas, existencialistas y coyunturales. La lucha con el maniqueísmo, con el donatismo y finalmente con el pelagianismo, impusieron a Agustín un modo de ver la "gracia divina», la acción de Dios en el mundo, la iniciativa sobrenatural en la reforma de la Iglesia, que el término "teología» parece descolorido y frío para expresar la hazaña de Agustín y el calor humano de su pensamiento reformista y «endiosado», o «entusiasta». Algunos han querido suavizar el término mística y nos han dicho que Agustín era, no místico sino «entusiasta». Puede pasar esa fórmula, si entendemos el término en su sentido etimológico. Quizá el término entusiasmo, endiosamiento, quiere decir todavía más que el término mística, cuando esta se queda en discusiones académicas.

He procurado aquí enfocar el problema de la evolución del monacato de Agustín desde su idea radical de la "perfección». Ese monacato queda abierto a un gran abanico de posibilidades que todavía no han sido ensayadas ni explotadas, pero que pueden serlo, si las circunstancias eclesiásticas lo demandan. Esa capacidad de soluciones da idea del grandioso proyecto de Agustín, y de la utilidad de su milicia cristiana para utilidad de la Iglesia, como problema eclesiástico general. Por eso, el problema agustiniano del monacato es hoy tan actual como en los tiempos del Santo. Tantos ensayos como hoy se planean deberán meditar ese modo de proceder de Agustín.

Sólo me queda referirme a un punto muy interesante; pero lo dejo, ya que lo he tratado en otra parte. Me refiero a la crisis radical que Agustín padeció en los comienzos de su episcopado: trató de fugarse a una soledad y de abandonar su puesto. Pero Cristo le dio la solución: «Cristo ha muerto por todos, para que los que viven no vivan para sí, sino para Aquel que murió por todos, por el Christus totus». Es otro tipo de mística, que Agustín, al superar esa crisis dejó consignado en una epístola maravillosa y célebre ${ }^{79}$. Esa es ya la mística del Christus totus, aplicada al monacato.

LOPE CILlERUELO

79. Ep. 48,1-4 PL 33,187. 